\title{
Impact of human resources management on business result of Croatian construction companies
}

\author{
Ivana Šandrk Nukić \\ Faculty of civil engineering, \\ J.J.Strossmayer University, Osijek, Croatia \\ isandrknukic@gfos.hr
}

\author{
Nenad Šuvak \\ Department for mathematics, \\ J.J.Strossmayer University, Osijek,Croatia \\ nsuvak@mathos.hr
}

DOI 10.5592/otmcj.2013.1.3

Research paper

\section{Keywords}

Management, Human

Resources Management,

Construction, Competitiveness,

Performance
IT HAS BEEN WIDELY RECOGNIZED THAT ACTIVITIES PRACTICED BY HUMAN RESOURCES MANAGEMENT (HRM) SIGNIFICANTLY INFLUENCE BUSINESS PERFORMANCE OF ANY COMPANY. However, quantification of that relationship has not been researched enough to provide a tool for practitioners by which they could increase their business result. Therefore additional scientific contribution on the subject would be valuable and that is the very purpose of this paper.

Authors of this paper have researched what is the impact of HRM activities in construction industry in Croatia. After an insight into a theoretical background about influence of HRM activities on business performance, this paper presents results from their own study. The research was conducted over actual financial results realised before and during the period of recent economic crisis, from 2007-2010. Data was collected using financial data base Poslovna.hr and the opinion poll conducted in more than $30 \%$ of middle-size construction companies in Croatia. Data was analysed using frequency analysis, analysis of correlation coefficients and finally by construction of multiple linear regression models.

Results of the research suggest that people working in construction have reached the subsistence level income. Constructed multiple linear regression models indicate that, among other human resources activities, the material motivation activities have the most significant positive impact on business result. Professional selection of candidates, life long learning, supportive organizational culture and other non-material measures remain for the benefit of some future times. 


\section{INTRODUCTION}

During the last couple of decades it has been widely researched and consequently accepted that efficient HRM significantly determines competitive advantage and business success of a company (Barney, 1995, 2001; Pfeffer, 1994; Huselid, 1995; Huselid et al., 1997; Fitz-enz, 1995, 2000; Becker and Gerhart, 1996). However, there has been not enough evidence that actually measures the impact of HRM, especially in the context of recent economic crisis.

Analysis of Croatian economy during the last years has shown that the country faced severe recession that started in 2009 and resulted in general slowdown in economic activity, fall of gross domestic product and expected rise of unemployment rate.

of course, in the situation like this, new production and investments should be the key element of economic recovery. But, the motive of this research is quantifying the factor that lies beneath any business initiative including new production and investments. And that is people.

Furthermore, this paper deliberately researched the impact of HRM exclusively in construction segment of Croatian economy. Construction is one of the leading indicators of economic cycles. On one side, OECD considers Construction as one of the Main economic indicators (MEI) (www.oecd.org), as well as the Conference Board of the USA defines The 10 Components of Leading Indicators (http://www.conferenceboard.org), among which are Building permits for new private housing units. On the other hand, civil engineering works are the foundation of any new investment. Especially investments in transport infrastructure led Croatian economy through its boom and contraction during the last decade.
Construction is an important segment of Croatian economy with moreless stabile contribution of $6-7 \%$ during the research period from 2007-2010 (see Table 2). But, it must be emphasized that its nominal value of works performed changed significantly. Such a trend can be seen in Table 2., showing the value of works done, contribution of construction to the GDP, number of employees and productivity per employee.

Positive trends in construction culminated by 2008. After that, severe fall of annual value of works done, employees and productivity indicated beginning of recession in construction and Croatian economy in general. Total value of construction works done fell in 2011 for $40,4 \%$ in comparison to 2008 !

Obviously, in 2008 ended the main wave of big investments both in building construction and in civil engineering, so the companies were forced to adjust their grown capacities.

In such a context, only people can make a positive difference and change the trend. Therefore, authors find it very important to research contribution of HRM to business result of construction companies.

\section{Theoretical background}

Development and importance of human capital concept

When thinking of people as an element that makes a difference in business performance, we actually think of people as human capital. "Human capital is seen increasingly as a key determinant of economic performance. A key strategy in determining economic performance has been to employ a conception of individuals as human capital and various economic metaphors such as 'technological change', 'research', ‘innovation', 'productivity', 'education', and 'competitiveness'” (Fitzsimons, 1999).

In the 18th century Adam Smith in his book The Wealth of Nations (1776) formulated the basis of what was later to become the science of human capital. He argued the contribution of human knowledge, skills and activities to wealth of society as a whole. (Samuelson and Nordhaus, 1993).

After Smith, several famous economists shared the idea. In his analysis of factors of production, Karl Marx emphasized know-how of workers. Alfred Marshall distinguished personal and organizational capital, but accented that knowledge was the most powerful production generator (Bahtijarević Šiber, 1999).

Nevertheless, systematic research of human capital was intensified during 1960s. It were the researchers from the University of Chicago who invented the concept and the very term of human capital (www.efzg.hr/ Mali leksikon odgoja, obrazovanja i školstva, prof.dr.sc. Vinko Barić). Studies done by Paul A. Samuelson, Kenneth J. Arrow, Herbert Simon, Friedrich A. van Hayek, Milton Friedman, George Stigler and Theodore Schultz made the most significant contribution to cognition of importance of investments into human resources as well as impact of human resources development on productivity (Bahtijarević Šiber, 1999).

In market valorisation of human resources investments' effects, especially the work of Theodore Schultz should be highlighted. He said that investments into human resources must be considered as the most important alternative to investments into material factors of production. According to him, those investments have even bigger return than material investments because they contribute to productivity

\begin{tabular}{|l|c|c|c|c|c|}
\hline & 2007 & 2008 & 2009 & 2010 & 2011 \\
\hline GDP, \% & 5,1 & 2,2 & $-6,0$ & $-1,2$ \\
\hline
\end{tabular}

Table 1 Gross domestic product (GDP) in Croatia / Source: Croatian Bureau of Statistics, www.dzs.hr 


\begin{tabular}{|c|c|c|c|c|c|c|c|c|}
\hline Year & $\begin{array}{c}\text { Total } \\
\text { revenue in } \\
\text { construction }\end{array}$ & $\begin{array}{c}\text { Value of } \\
\text { works done }\end{array}$ & $\%$ & $\begin{array}{c}\text { Contribution } \\
\text { of } \\
\text { construction } \\
\text { to GDP }\end{array}$ & $\begin{array}{l}\text { Number of } \\
\text { employees }\end{array}$ & $\%$ & $\begin{array}{c}\text { Productivity } \\
\text { per } \\
\text { employee }\end{array}$ & $\%$ \\
\hline & (mil.HRK)* & $(.000 \mathrm{HRK})^{\star}$ & (\%) & (\%) & $(z)$ & (\%) & $(€ / z)$ & (\%) \\
\hline 2001. & $23 \cdot 510$ & 8.805 .313 & 100 & 4,1 & 65.782 & 100 & 17.922 & 100 \\
\hline 2002. & 28.784 & 11.509 .034 & 131 & 4,5 & 71.788 & 109 & 21.645 & 121 \\
\hline 2003. & 37.443 & 16.190 .009 & 184 & 5,4 & 80.089 & 122 & 26.727 & 149 \\
\hline 2004 . & 41.327 & 16.899 .253 & 192 & 5,7 & 84.642 & 129 & 26.638 & 148 \\
\hline 2005 . & $44 \cdot 560$ & 17.807 .328 & 202 & 5,6 & 89.524 & 136 & 26.879 & 150 \\
\hline 2006. & $53 \cdot 351$ & 21.430 .104 & 243 & 5,9 & 95.249 & 145 & 30.724 & 171 \\
\hline 2007. & 57.951 & 24.299 .155 & 276 & 6,0 & 104.142 & 158 & 31.806 & 177 \\
\hline 2008. & 69.230 & $34 \cdot 915 \cdot 314$ & 397 & 6,2 & 108.260 & 165 & 44.033 & 246 \\
\hline 2009. & 58.462 & $30.714 \cdot 772$ & 349 & 7,0 & 97.503 & 148 & 43.009 & 240 \\
\hline 2010. & $47 \cdot 713$ & 22.808 .572 & 259 & 5,8 & 91.052 & 138 & 34.201 & 191 \\
\hline 2011. & 44.820 & 20.821 .802 & 236 & - & 83.607 & 127 & 34.001 & 190 \\
\hline $\begin{array}{l}\text { I-XII } \\
2011 / \\
I-X|| \\
2008\end{array}$ & $\begin{array}{l}\text { Less for } \\
35,3 \%\end{array}$ & Less for: & 40,4 & - & Less for: & 22,8 & Less for: & 20,5 \\
\hline
\end{tabular}

* 1 EUR = 7.58 HRK (http://www.hnb.hr/tecajn/htecajn.htm, 30.1.2013.) Source: www.hgk.hr;

Review of the Basic Statistics in the Construction Sector in Croatia, the period January-June 2012, p 2

Table 2 Croatian construction industry: value of works done, contribution of construction to the GDP, number of employees and productivity per employee for the period $\mathbf{2 0 0 0 - 2 0 1 0}$

of labour and enhance entrepreneurial capabilities (Schultz, 1985:19).

Such an attitude was maintained in later decades, too. For example, it is stated that the overall economic performance of the OECD countries is increasingly more directly based upon their knowledge stock and their learning capabilities (Lundvall, 1996).

It has been recognized that investments into human capital are important because of their quantitative effects (increase of income) but also of their qualitative dimension. This qualitative dimension is immanent in enhancement of entrepreneurial capabilities, increase of flexibility and adjustability to changes as well as contribution to development of life-long-learning culture (Bahtijarević Šiber, 1999).

For all those reasons, research on impact of HRM and knowledge management on business performance and competitiveness has been intensified since the end of the 2oth century so numerous studies were undertaken to explore the connection of human capital (human resources) with business result.

In the first phase, during 1980 s, the work of Theodore Schultz (Schultz, 1985), research of M. A. Devanna, C. Fombrun and N. Tichy (Devanna et al., 1981 and 1982; Tichy et al., 1982), and studies that came out of project
OASIS, the most important project for development of strategic HRM at the time (Ulrich et al., 1984; Ulrich, 1997; Schuler and Jackson, 1987; Jackson et al., 1989), undoubtedly confirmed the connection of human capital and HRM with business result.

In the next phase, researchers tried to quantify that relationship. Two of those studies are the most prominent. So called $\mathrm{CCH}$ study measured and established positive impact of human resources' activities on 4 performance indicators: market and book value ratio, income per employee, market value of the company and sales income (Ulrich, 1997). The other was the study of pro- 
fessor Mark Huselid and his associates from Rutgers University. His research comprised 968 companies with more than 100 employees and examined the HRM activities' impact on total revenue, sales income per employee and net income. (Huselid, 1995).

As a result of those studies, HRM has been transformed from an operative business function into a strategic tool for realisation of superior business performance and sustainable market competitiveness.

\section{Human resources management in construction industry}

After the initial studies of HRM impact on business result during 1980s, the next decade was characterised by more focused studies. They measured that impact either in terms of a specific HRM activity (Borman, 1991; Gerhart and Milkovich, 1992; Terpstra and Rozell, 1993), either in a specific industry (Arthur, 1994; MacDuffie, 1995).

One of the first focused studies of HRM regarding construction industry was conducted by J. Drucker, G. White, A. Hegewisch and L. Mayne in 1996 (Drucker et al., 1996). "Construction is managed by people who are concerned with cost and production. They are more influenced by the value of "harder" personnel issues and it is a challenge to achieve credibility for "softer" issues!" But, besides identifying such a current state, the survey results suggested also that evident challenge for HRM in construction is related to training and employee development.

Other studies of HRM impact on business performance in construction at that time confirmed those findings. Maloney says: "The rate of change in external environments of construction organizations is increasing, which necessitates that increased attention be paid to strategic planning and, in particular, strategic planning for human resource management. (...) Strategies tend to be emergent.
With the changes taking place in its external environments, a construction organization must attempt to develop deliberate human resource management strategies. In developing these strategies, a construction organization must address issues such as (...) workforce diversity, and the availability of a skilled workforce." (Maloney, 1997:49)

Importance of soft issues like training and motivation has been identified also in a study undertaken by Castañeda, Tucker and Haas: "Several diverse factors have contributed to the construction industry's shortages of skilled workers; these factors include decreased real wages, transient nature of work, poor industry image, lack of training, and lack of a worker-oriented career path. The consequent impact of this problem on project performance has been reported with increasing frequency over the last few years" (Castañeda et al., 2005:799). A new work force management strategy, which would utilize fewer, better-educated workers, who would receive higher compensation and deliver improved results, has been proposed to address the problem. The strategy has been proven as feasible and achievable.

The latest research of HRM in construction industry stated that human resource practices are mostly concerned with gaining value through increased skills, productivity, autonomy, contribution, and cost consciousness. Whilst, productivity is one of the most important factors affecting the overall performance of any construction company (Arashpour and Arashpour, 2011). In a survey of 120 construction companies, Arashpours researched the hypothesis that although financial factors are very important in affecting productivity, the contribution of psycho-social factors (from a domain of HRM) does play an important role in productivity improvement and gaining value, especially through labour-intensive industry of construction. $91,4 \%$ of respondents agreed with that hypothesis.
The most comprehensive work dealing with strategic HRM as a route to improving business performance of construction companies has been done by Martin Loosemore, Andrew Dainty and Helen Lingard. Their first book on the topic, Human Resource Management in Construction Projects: Strategic and Operational approaches (2003), starts with identification of problems related to HRM in construction and ends with references for application of strategic HRM with a goal of performance improvement. The book also provides description of construction industry specificities, especially in terms of distinction between office and field workers, dislocated work sites that constantly change, and dependence on subcontractors, mostly craft workers who are naturally more related to their trade than to a company that hired them. The last but not least, authors emphasize the difference between strategic HRM and personnel management and indicate the importance of training and its measurement for better performance. In so doing, the authors suggest that three most important operational aspects of strategic HRM are: employee resourcing, human resources training and development and reward management. They say: "It is important to recognize the potential of socio-economic role of HRD in enhancing the wellbeing and performance of the industry." (Loosemore et al., 2003:255). In their latest book, Human Resource Management in Construction: Critical Perspectives (2011), they say: “Despite its size and socio-economic significance, the construction sector remains a poorly understood industry, particulary in relation to its people management practices (Dainty and Loosemore, 2012:1).

Generally, research of HRM has come to the point at which positive impact of HRM is not doubted, but different measurement systems of that impact are being developed and implemented (Phillips,1996; Fitz-enz, 2000; Ulrich 1997; Huselid 1994; Becker et al., 2001; 
Becker and Huselid 2003). However, in construction industry this measurement is still a niche with not enough scientific contributions.

There has been an interesting study of drivers of productivity among construction workers in a developing country, undertaken by Kazaz and Ulubeyli (Kazaz and Ulubeyli, 2007). A survey of 82 construction firms in Turkey, based on quantitative and qualitative factors that affect labour performance, has led to results that "show that monetary factors remain pre-eminent in influencing productivity, but that socio-psychological factors appear to be of increasing importance" (Kazaz and Ulubeyli, 2007: 2132).

In Croatia, the most important studies regarding HRM practices and their measurement have been conducted by Sveto Marušić (Marušić, 1999, according to Pološki Vokić and Vidović, 2008) and Nina Pološki Vokić (Pološki Vokić 2004, Pološki Vokić and Frajlić 2004, Pološki Vokić and Vidović 2008). The studies have been undertaken mutually independently but they have certain similarities. They've been conducted over companies from different industries and they found out that although there is a significant correlation of certain HRM activities with business performance, HRM in Croatia is rather underdeveloped.

Furthermore, according to their recommendations, HRM should be researched not only in economy as a whole, but also in specific industries, in order to identify and understand their characteristics. Since we stated before that construction industry has both the importance and potential for that kind of research, authors of this paper found those reasons as an indication of a need for an additional scientific contribution. Therefore they examined and measured impact of different HRM activities on financial indicators of business performance in middle-size construction companies in Croatia.
Empirical research and

methodology used

Our empirical research has been conducted over medium-size construction companies in Croatia, with 50 - 250 employees. Sample of 102 companies was formed by random sampling. Total population of medium sized companies in Croatia is less than 300 (www.dzs. hr), so such a big sample was formed in order to create a valid quantitative model. Furthermore, it provides an additional soundness of the results.

Following one of the most influential HRM measurement studies done by Huselid and Delaney (Huselid and Delaney, 1996), the initial research question of our research were associations of HRM practices and firm performance measures in Croatian construction industry.

Of course, firm performance depends on many factors, but as elaborated in chapter on theoretical background, HRM activities are proven to have a significant impact on business result. Since HRM activities are an internal element, something that a company can influence on, we thought it would be interesting to examine which activities exactly and how determine the value of different performance measures.

Knowing that, companies would gain a powerful tool they could use to make a positive change, to generate additional value in terms of business result. Therefore, beside the correlations between named elements, we also modeled the value of different performance measures using multiple linear regression.

The one-time basis data collection was conducted using opinion poll for collection of data on HRM activities practiced in a company as well as data ensuring that population under consideration is of the similar size and structure. Financial data acquisition regarding firm performance was done using the official financial portal Poslovna Hrvatska (www.poslovna.hr).

Appreciating the most important operational aspects of strategic HRM identified by Loosemore, Dainty and Lingard (2003) - employee resourcing, human resources training and development and reward management, the opinion poll used has been consisted out of selected key HRM activities, structured as 4 groups of variables:

1. Selection of employee candidates - variables including planning of number and the structure of employees as well as so designated acquisition and selection of employees

2. Life long learning and on-job training - variables that are related to education and continuous development of employees' know-how

3. Motivation - variables concerning work efficacy monitoring and assessment, and consequently supervened remuneration of work

4. Knowledge transfer and organizational culture management variables that provide information regarding knowledge transfer inside the company, along its value chain, and moreover among different market subjects

Variables from these four groups will be treated as independent (predictor) variables in modeling procedure. As such, these predictor variables will be used for modeling the value of different firm performance measures, which therefore we treat as the dependent model variables.

Dependent variables on firms' performance are collected from the official financial reports from 2007 till 2010 (www.poslovna.hr).

The last section of the opinion poll referes to 7 control variables, ensuring the homogeneity of the sample. These control variables are also used as predictors in the modeling of above mentioned dependent variables.

We provide the list of independent and control variables in Table 3.

Data was analysed in a way that interviewed HR managers (who most often were in fact owners and general managers of the firm) were asked to grade qualitative predictor variables using the 


\section{INDEPENDENT VARIABLES}

\section{SELECTION}

A.1.1.

A.1.2.

A.2.1.

A.2.2

A.2.3.

A.2.4.
Average number of job applications per job position

Use of professional tests and specialized agencies for job candidates assesment

\section{EDUCATION AND TRAINING}

Analysis of educational needs and choice of training programmes accordingly

Percentage of employees that have been provided scholarship for further higher education

Percentage of employees who attend on job training

Grade of quality, adequacy and quantity of educational programmes provided for employees

\section{MOTIVATION}

A.3.1.

Quality of work performance evaluation system practiced by the company

A.3.2. Influence of the work perfomance on salary and other forms of material compensation

A.3.3. Importance and appreciation of employees' opinion and ideas

A.3.4.

Probability of promotion in dependence on work performance

A.3.5.

Average net monthly salary per employee

A.3.6.

Average gross monthly costs per employee

\section{KNOWLEDGE TRANSFER}

A.4.1.

Efficiency of providing feedback on work completition

A.4.2.

Efficiency of archiving and accessing business data and information

A.4.3.

Efficiency of learning from business partners

A.4.4.

Efficiency of transfering company's know-how to partners and customers

A.4.5.

Value of company's contribution to upgrade of construction

A.4.6.

Activities regarding knowledge transfer after appearance of recession in Croatia

\section{CONTROL VARIABLES}

C1 Date of company's foundation

$\mathrm{C}_{2}$

Total number of employees

$C_{3}$

Value of total assets

$\mathrm{C}_{4}$

Value of capital and reserves

$\mathrm{C}_{5}$

Average age of employees

$\mathrm{C}_{7}$

Structure of employees in respect of education level

Table 3 Independent and control variables 
1-5 scale, and to provide actual numbers or percentages for quantitative predictor variables.

1-5 scale was used to grade degree of conformance with specific assertion. For example, for variable A.2.1. Analysis of educational needs and choice of training programmes accordingly, grade 1 as the lowest possible grade would mean that analysis of educational needs and appropriate choice of training programmes does not exist at all in that company. Subsequent grades express higher degree of conformance, up to grade 5 meaning analysis of educational needs and choice of training programmes are fully adequate to company's business scope and efficient.

Several predictor variables were not qualitative in their nature, so for their description managers were asked to provide percentages (i.e. relative frequencies). For example, for variable A.2.3. Percentage of employees who attend on job training, interviewed managers provided a percentage of such employees for each year from the research period 2007-2010, out of which an average frequency for the period was calculated and taken into further account.

Evaluation was carried out through several phases:

5. Frequency analysis is used to learn about the nature of variables, out of which results on control variables will be presented in Section 3. This phase provides better understanding of sample structure, its homogeneity and moreover, the very business practice and performance of evaluated companies.

6. Analysis of correlation coefficients between predictor variables, as well as between predictors and dependent variables.

7. Construction of multiple linear regression models, based on 24 predictor variables listed in the Table 3.

8. Analysis and interpretation of constructed multiple linear regression models. For all models their strength and adequacy were analyzed. Strength was analyzed according to coefficient of determination and for adequacy we used the standard T-test for testing the statistical hypothesis weather the model under consideration is better than the model excluding the specific predictor variable.

\section{Results of frequency analysis and correlations}

After data was collected, the first step was to learn about nature and relations of relevant variables. These findings are presented below.

\section{Frequency tables for control variables}

In order to ensure comparability of results, it was very important to make sure that research is conducted over a homogeneous sample. Therefore, as the first step, special attention was paid to descriptive statistics of control variables.

Age of the company has been analysed as the first control variable. The assumption was that similar oldness ensures having the same tradition and experience both in construction and in HRM. Frequency table of this variable showed that majority of selected companies ( $49 \%$ ) has been founded more than 10 but less than 20 years ago. $17 \%$ of companies is younger than 10 years of age, and $19 \%$ of companies is more than 20 but less than 30 years old. There are only few companies with more than 30 years of experience. Such results have been taken as acceptable.

Secondly, average number of employees during the 4 year period from 2007 till 2010 was analysed as the control variable, too. Frequency table showed that out of 102 analysed companies, $58,8 \%$ of companies has more than 50 and less than 100 employees. Further $30,3 \%$ of companies has more than 100 and less than 200 employees. Only 8 companies have less than 50 employees and only 3 companies have more than 200 but less than 250 employees. Such a distribution of number of employees was assumed to secure the appliance of similar human resources policy in the sample under consideration.

Beside number of employees, values of assets and capital were also analysed as measures for securing the sample of similar size companies. Total assets value (average value from 20072010) was recorded to be between 2 mil. and 6 mil. EUR for $53,7 \%$ companies, and capital value is under 3 mil. EUR for $81,5 \%$ of analysed companies. These numbers confirmed already stated homogeneity of sampled construction companies.

Maybe not so important but nevertheless interesting control variables are average age of employees and gender structure of employees, analysed for period from 2007 till 2010. The youngest average age of employees in a single company has been recorded to be 36 years of age. Furthermore, great majority of sample companies $(79,4 \%)$ have the average age of their employees between 38 and 46 years of age. This result could be an indicator of the high unemployment rate of young engineers in the construction industry in Croatia. Gender structure drew up as another significant similarity. Portion of male employees is at least $82 \%$ in all of the analysed construction companies!

In the end, structure of employees based on their education has been analysed as the last control variable. Obviously the same core business absolutely determines the education structure of employees, because population under consideration showed remarkably matching results: 74 companies (73\%) have between $18-23 \%$ of operatives, 77 companies ( $76 \%$ ) have between $59-65 \%$ of employees who finished only secondary school, 91 companies ( $89 \%$ ) have from $5 \%$ to $12 \%$ of bachelors and 89 companies $(87 \%)$ have more than $5 \%$ and less than 


\begin{tabular}{|c|c|c|c|c|}
\hline $\begin{array}{c}\text { Dependent } \\
\text { variable name }\end{array}$ & $\begin{array}{c}\text { Dependent } \\
\text { variable description }\end{array}$ & Multiple - R & Multiple - R2 & Adjusted - R2 \\
\hline B.2.1. & Average revenue, in million EUR & 0.8935 & 0.7984 & 0.7356 \\
\hline B.2.2. & Average costs, in million EUR & 0.8816 & 0.7773 & 0.7079 \\
\hline B.2.3. & Average net income, in thousands EUR & 0.9673 & 0.9357 & 0.9157 \\
\hline B.2.4. & Average newly created value, in million EUR & 0.9603 & 0.9223 & 0.8981 \\
\hline B.2.5. & Average current liquidity coefficient & 0.9742 & 0.9491 & 0.9332 \\
\hline B.2.6. & Indebtedness level in \% & 0.7187 & 0.5166 & 0.3659 \\
\hline B.2.7. & Average turnover of total assets & 0.6199 & 0.3844 & 0.1925 \\
\hline B.2.8. & Average economy of total business & 0.6211 & 0.3859 & 0.1944 \\
\hline B.2.9. & Average net income per employee & 0,9376 & 0,8792 & 0,8431 \\
\hline B.2.10. & Average productivity & 0.9622 & 0.9260 & 0.9029 \\
\hline
\end{tabular}

\section{Table 4 Comparison of constructed models}

$10 \%$ of employees who graduated from college. Minor discrepancy regarding education structure has been recorded in remaining companies.

These six control variables were included in further modeling of variables providing information on firms' performance recorded in official financial reports from 2007 till 2010. Seventh control variable regarding gender structure of employees was left out due to its shown irrelevance for the final value of dependent variables. However, this variable also confirmed the homogeneity of the sample.

\section{Correlations}

After frequency analysis which provided better understanding of the sample, it was important to study correlation coefficients between predictor variables as well as predictors and dependent variables.

To avoid information overload, this paper will not present all estimated correlation coefficients. It is enough to say that, at the significance level 0.05 , we can accept the hypothesis that the correlation coefficients between majority of observed variables are different from zero, i.e. at the significance level 0.05 we can accept the hypothesis that the variables in question are correlated.

In addition to that, it must be said that majority of estimated correlation coefficients between predictors and dependent variables are positive higher values of the variables dealing with the activities of the HRM are paired with the higher values of the variables dealing with the business results.

There are only two negative estimated correlation coefficients. First is expected because it concerns the level of financial leverage used. It suggests that the higher values of the variables dealing with the activities of the HRM are paired with the smaller values of the variables dealing with the indebtedness level of a company. But the second negative correlation is somewhat odd and it suggests that the higher values of the average age of employees are paired with the lower values of the business results of a company. We comment this finding in respect of critically high average age of employees detected by previously presented frequency analysis. This could suggest that the average age of employees has reached the level at which any further increase directly means the aggravation of business result.

\section{Modeling the value of dependent variables using multiple linear regression}

After frequency analysis and analysis of correlations, multiple linear regression models were constructed for all dependent variables, i.e. variables dealing with business results. As previously stated, models were based on 24 predictor variables (see Table 3 ).

If $Y$ denotes the dependent variable in question and $X i, i \in\{1, \ldots 24\}$, denote predictor variables, then the multiple linear regression model is the model of the form

$$
Y=a+\sum_{i=1}^{24} \beta_{i} X_{i}+\varepsilon,
$$

where $a$ and $\beta i, i \in\{1, \ldots 24\}$, are regression parameters whose theoretical values are unknown, but could be estimated by the least squares method (estimated values for the purpose of this paper are calculated in the statistical software Statistica 10 ), and $\varepsilon$ is the random variable that describes the error of the presented model. Detailed 
description of the multiple linear regression models could be found in Šošić (2006).

For example, the equation of the multiple linear regression model for the average current liquidity coefficient (variable B.2.5.) is of the, where the estimated value of the regression coefficient a (intercept) is (-61.014) and estimated values of the regression coefficients $\beta i, i \in\{1, \ldots 24\}$, are given in the Table 5 .

In that table regression coefficients $\beta i, i \in\{1, \ldots 24\}$, are ordered and numbered according to the predictors listed in the Table 3 (e.g. $\beta_{1}$ is the coefficient multiplying the variable A.1.1., here denoted by $\mathrm{X}_{1}$ ).

The following analysis of multiple regression models is performed to examine if the models of this type are suitable for modeling of the variables listed in the Table 4 and to identify the predictor variables that have the most significant impact in the model.

\section{Model strength}

It is known that the value of the determination coefficient R2 (see Table 4) gives an information on how well the linear function, defined in terms of predictor variables, describes the dissipation of the measured values of the dependent variable in question, i.e. it gives an information on the strength of the linear functional relationship between the predictors and the dependent variable. R2 values close to one suggest that the functional relationship between the predictors and the dependent variable is well described by the linear function, i.e. it suggests that the linear model is strong.

Namely, it is often interpreted that $100 *$ R $2 \%$ dissipation of the measured values of the dependent variable, with respect to its values predicted by the linear function, could be explained by the multiple linear regression model. The rest of $\left(1-\mathrm{R}_{2}\right){ }^{\star} 100 \%$ of this dissipation could not be explained by the linear model and therefore it is called the unexplained or residual dissipation.

The Table 4 shows that multiple linear regression models constructed for 10 dependent variables are very strong (i.e. the dissipation of the measured values of these dependent variables with respect to its predicted values is well described by the linear function), except for variables B.2.7. and B.2.8. The measured values of these dependent variables are not well enough described by the linear model and therefore the additional research should be conducted to find the more appropriate model.

But on the other hand, it is worth emphasizing that all other linear models are very strong. Especially models for dependent variables B.2.3. (average net income is thousands EUR), B.2.4. (average newly created value in million EUR), B.2.5. (average current liquidity coefficient), and B.2.10. (average productivity), with determination coefficient higher than 0.9. Such $\mathrm{R} 2$ value indicates that more than $90 \%$ of the dissipation of the measured values of the dependent variable in question is explained by the linear model. This finding suggests that for modeling of company's performance the multiple linear regression models based on predictors dealing with selection procedures, training and education, motivation activities and knowledge transfer in a company and its surrounding are appropriate.

\section{Model adequacy}

Table 4. also shows the Adjusted-R2 coefficient, which is known to be a good measure of model adequacy (Šošić, 2006). As opposed to determination coefficient (Multiple- R2 which takes into account only number of available data - in this case 102), it takes into consideration also the number of predictor variables (in this case 24).

Furthermore, in order to test the adequacy of the created models, i.e. to test if a certain predictor variable is significant in the model, for each of the regression parameters $\beta \mathbf{i}, \mathbf{i} \in$ $\{1, \ldots, 24\}$,T-test has been conducted

\begin{tabular}{|c|c|c|c|c|c|}
\hline$\beta 1$ & $\beta 2$ & $\beta 3$ & $\beta 4$ & $\beta 5$ & 0.4361 \\
\hline-0.0109 & 0.1134 & -0.0656 & 29.9534 & -0.8544 & $\beta 12$ \\
\hline$\beta 7$ & $\beta 8$ & $\beta 9$ & $\beta 10$ & $\beta 11$ & -0.0331 \\
\hline 0.4951 & 0.4993 & -0.2111 & -0.1584 & $\beta 18$ \\
\hline$\beta 13$ & $\beta 14$ & $\beta 15$ & $\beta 16$ & $\beta 17$ & -0.6571 \\
\hline-0.2164 & -0.2164 & 0.0636 & 0.2912 & -0.3457 & $\beta 24$ \\
\hline$\beta 19$ & $\beta 20$ & $\beta 21$ & $\beta 22$ & $\beta 23$ & 14.5160 \\
\hline 0.0262 & -0.0054 & -0.0000 & 0.0000 & 0.1175 & \\
\hline
\end{tabular}

Table 5 Estimated values of the regression coefficients $\beta i, i \in\{1, \ldots 24\}$, for the variable B.2.5. 


\section{Dependent variable}

Dependent variable

B.2.1. average revenue, in million EUR

B.2.2. average costs, in million EUR
B.2.3. average net income, in thousands
EUR

B.2.4. average newly created value, in

B.2.4. avera
million EUR

B.2.5. average current liquidity coefficient

(2)

(20)

\section{B.2.9 average net income per employee}

B.2.10. average productivity
Independent variable with statistically significant impact

A.3.5. average net salary per employee, in EUR

\section{C.2 number of employees}

C.3 value of total assets, in million EUR

C.2 number of employees

C.3 value of total assets, in million EUR

A.3.5. average net salary per employee, in EUR

A.3.6. average total monthly costs per employee, in EUR

C.4 value of capital and reserves, in million EUR

A.3.5. average net salary per employee, in EUR

A.3.6. average total monthly costs per employee, in EUR

C.2 number of employees

C.4 value of capital and reserves, in million EUR

A.3.5. average net salary per employee, in EUR

A.3.6. average total monthly costs per employee, in EUR

C.4 value of capital and reserves, in million EUR

A.3.5. average net salary per employee, in EUR

A.3.6. average total monthly costs per employee, in EUR

C.4 value of capital and reserves, in million EUR

C.7 educational structure of employees

A.3.5. average net salary per employee, in EUR

A.3.6. average total monthly costs per employee, in EUR

\section{C.2 number of employees}

C.4 value of capital and reserves, in million EUR
Estimated regression parameter and the p-value

$p=0,008255 ; \beta=16346$

$p=0,000206 ; \beta=53595$

$\mathrm{p}=0,000000$

$\beta=1$

$p=0,000081 ; \beta=53970$

$p=0,000000 ; \beta=1$

$p=0,000000 ; \beta=8982$

$p=0,000000$;

$\beta=-5196$

$p=0,000009 ; \beta \approx 0$

$p=0,000000 ; \beta=9300$

$\mathrm{p}=0,000000$;

$\beta=-4526$

$p=0,000000 ; \beta=14818$

$p=0,000007 ; \beta \approx 0$

$p=0,000000 ; \beta=0,0580$

$\mathrm{p}=000000$

$\beta=-0,0331$

$p=0,000454 ; \beta \approx 0$

$p=0,000000 ; \beta=148$

$\mathrm{p}=0,000000$

$\beta=-90$

$\mathrm{p}=0,003181$;

$\beta \approx 0$

$p=0,038310 ; \beta=107776$

$p=0,000000 ; \beta=174$

$\mathrm{p}=0,000000$;

$\beta=-92$

$\mathrm{p}=0,018766$;

$\beta=-66$

$p=0,000059 ; \beta \approx 0$ 
( $\left.\mathrm{Ho}_{0}: \beta i=0, H_{1}: \beta i \neq 0\right)$. Values of the test statistics and $p$-values for the T-test are calculated in the statistical software Statistica 10. At the significance level $a=0.05$ hypothesis $\mathrm{Ho}$ is rejected only if the corresponding $\mathrm{p}$-value of the T-test is less than 0.05 . In those cases alternative hypothesis is accepted, which means that the created model including the predictor variable $\mathrm{Xi}$ with estimated regression coefficient $\beta i$ is better than the model in which $\beta \mathrm{i}=0$ and which therefore doesn't include the predictor variable $\mathrm{Xi}$.

An overview of Adjusted-R2 coefficients presented in the Table 4 suggests that constructed models are adequate, again with exception of models for dependent variables B.2.6., B.2.7. and B.2.8. These dependent variables are not adequately modelled by the multiple linear regression and additional research should be conducted in order to model their measured values.

All other dependent variables recorded high Adjusted-R2 coefficients $(0,71-0,93)$, suggesting adequacy of models constructed for their interpretation.

\section{Interpretation of models}

At the first glance of Table 6, it is obvious that material motivation variables A.3.5. (average net salary per employee) and A.3.6. (average total monthly costs per employee) have more significant impact on the measured values of dependant variables than other predictors.

of course, impact of material motivation variables is understandable and could be interpreted. Such results suggest that companies with bigger financial accumulation (variable B.2.1.) have more assets to abstract for material motivation purposes. Vice versa, material motivation gives rise to further generation of significant revenues.

Furthermore, increase of net earnings in a company directly influences the increase of net income of that company (variable B.2.3.), showing that material motivation is still the most powerful motivation tool, among others. But, in the same time, the increase of gross costs per employee decreases net income of the employer, perhaps suggesting that taxes and other duties he is obligatory to pay in regard to his employees nullify the positive effect of material motivation.

Average monthly net salaries increase the newly created value, and gross monthly costs per employee decrease the newly created value. Since newly created value is calculated as sum of total salaries paid and total income earned, such relationship among variables involved in modelling the value of dependent variable B.2.4. is in accordance with previous assertion.

Currant liquidity coefficient (B.2.5.) reflects the ability of a company to fulfil its short term obligations and successfully perform short-term business activities. If this coefficient is not adequate, a company is facing difficulties in its everyday business, it has not enough assets for purchase of needed raw material and other goods, it has not enough money for salaries, taxes and other duties. On the other hand, companies with adequate currant liquidity ratio (when short-term assets/short-term obligations ratio approximately equals to 2) for sure have enough money on their account. Such companies should have enough money for salaries so it could be an explanation of a positive estimated regression coefficient related to the variable A.3.5. Again, A.3.6. shows a somewhat negative influence on the value of dependent variable B.2.5.

As in the model for dependent variable B.2.3., the results for dependent variable B.2.9. (average net income per employee) suggest that in order to achieve higher net income per employee, it is important to perform material motivation activities, as well as to have adequate capital level.
Since productivity (B.2.10) is calculated as newly created value per employee, this model shows expected similarity to previously presented model for dependent variable B.2.4. - it is significantly influenced by material motivation activities.

As said before, influence of material motivation activities has been expected. But what has not been expected is weak influence of other predictors! Results of analysis of models show their strength and adequacy, meaning that all predictor variables listed in the Table 6 have more significant impact on the values of the corresponding dependent variables with respect to other predictors.

\section{CONCLUSION}

Presented empirical research started with the assumption that „soft“ organizational variables have a significant impact on business performance of a company. Therefore, it measured influence of different HRM activities on business result of construction companies in Croatia.

It must be emphasized that the measurement was conducted in times before and during economic crisis, taking into account business result realised in period from $2007-2010$. Not just that period of 4 successive years contributed to the objectivity of results, but the very fact of present recession strongly determined the results.

Models presented in this paper suggest that, among other human resources activities, the material motivation activities (variables A.3.5. and A.3.6.) have the most significant impact on business results. This could be an indicator of difficult conditions in the Croatian construction industry, suggesting that people have reached the subsistence level income, at which living is only about basic existence and only material compensation matters. It would be interesting to investigate situation in more developed coun- 
tries, to learn at which level of income non-material compensation becomes significant.

In the end it could be recommended to employers in construction not to neglect the influence of HRM activities, especially material motivation, on performance of the company.

\section{References}

Arashpour, M. and Arashpour, M. (2011), Gaining the Best Value from HR in Construction Companies. Working Paper, available at http://www.iieom.org/ ieom2011/pdfs/ IEOM128.pdf.

Arthur, J. B. (1994), “Effects of human resource management systems on manufacturing performance and turnover", Academy of Management Journal, Vol. 37, pp. 670-687

Bahtijarević Šiber, F. (1999), Management ljudskih potencijala, Golden marketing, Zagreb

Barney, J. B. (1995), “Looking inside for competitive advantage", Academy of Management Executive, Vol. 9, No 4, pp. 49-61

Barney, J. B. (2001), "Is the resource-based view a useful perspective for strategic management research? Yes!”, Academy of management review, Vol. 26, No. 1, pp. 41-56

Becker, B., Gerhart, B. (1996), "The impact of human resource management on organizational performance: progress and prospects", Academy of Management Journal, Vol 39, No 4, pp. 779-801

Becker, B., Huselid, M. A. and Ulrich, D. (2001), The HR Scorecard - Linking People, Strategy, and Performance, Harvard Business School Press, Boston, MA, USA

Becker.B., Huselid, M. (2003), “Measuring $H R$ ? Benchmarking is not an answer”, HR Magazine, December, pp. 57-61

Borman, W.C. (1991), “Job behavior, performance, and effectiveness", in Dunnette, M.D. and Hough, L.M.: Handbook of industrial and organizational psychology, 2nd Ed. Palo Alto, CA: Consulting Psychologist Press, Vol. 2, pp. 271-326

Castañeda, J., Tucker, R., and Haas, C. (2005), “Workers' Skills and Receptiveness to Operate Under the Tier II Construction Management Strategy”, Journal of Construction Engineering Management, Vol. 131, No.7, pp. 799-807

Dainty, A., Loosemore, M. (2012), Human Resource Management in Construction: Critical perspectives, Routledge, Oxon

Devanna, M.A., Fombrun, C., Tichy, N. (1981), "Human Resources Management: A
Strategic Perspective", Organizational Dynamics, Vol. 9 Issue 3, pp. 51-67

Devanna, M.A., Fombrun, C., Tichy, N. (1982), "Strategic planning and human resources management", Human Resource Management, Vol. 21 Issue 1, pp. 11-17

Drucker, J., White, G., Hegewisch, A., Mayne, L. (1996), “Between hard and soft HRM: human resource management in the construction industry", Construction Management and Economics, Vol. 14, pp. 405-416

Fitzsimons, P. (1999), Encyclopedia of Philosophy of Education, http://www.ffst. hr/ENCYCLOPAEDIA/doku.php?id=human _ capital_theory_and_education

Fitz-enz, J. (1995), How to Measure Human Resources Management, McGraw-Hill, Inc., New York, NY, USA

Fitz-enz, J. (2000), The ROI of Human Capital Measuring the Economic Value of Employee Performance, AMACOM, New York, NY, USA

Gerhart, B., Milkovich, G.T. (1992), “Employee compensation: Research and practice", in: Dunnette, M. D. and Hough, L. M.: Handbook of industrial and organizational psychology. Palo Alto, CA: Consulting Psychologist Press, Vol. 3, pp. 481-569

Huselid, M. A. (1994), “Documenting HR's Effect on Company Performance”, HR Magazine, Vol. 39, No. 1, pp. 79-83

Huselid, A. M. (1995), “The impact of human resources management practices on turnover, productivity and corporate financial performance", Academy of Management Journal, Vol. 38, No.3, pp. $635-672$

Huselid, A. M., Delaney, T. J. (1996), “The impact of Human resources management practices on perceptions of organizational performance", Academy of Management Journal, Vol. 39, No.4, pp. 949-969

Huselid, A. M, Jackson, S. E., Schuler, R. S. (1997), “Technical and strategic human resource management effectiveness as determinants of firm performance", Academy of Management Journal, Vol.40, No.1., pp. 171-188

Jackson, S.E., Schuler, R., Rivero (1989), "Organizational characteristics as Predictors of personnel practices", Personnel Psychology, Vol. 42, pp. 727-786 
Kazaz, A., Ulubeyli, S. (2007), "Drivers of productivity among construction workers: A study in a developing country”, Building and Environment, Vol. 42, pp. 2132-2140

Loosemore, M., Dainty, M., Lingard, H. (2003), Human resource Management in Construction Projects: Strategic and Operational approaches, Spon Press, London

Lundvall (1996), “The knowledge-based economy: From the economics of knowledge to the learning economy”, in Employment and Growth in the Knowledge-based Economy, OECD Documents, Paris: OECD

MacDuffie, J. P. (1995), “Human resource bundles and manufacturing performance: Organizational logic and flexible production systems in the world auto industry", Industrial and Labor Relations Review, Vol. 48, pp.197-221

Maloney, W. F. (1997), “Strategic planning for human resource management in construction", Journal of management in engineering, Vol. 13, No.3, pp. 49-56

Pfeffer, J. (1994), “Competitive Advantage through People”, California Management Review, Vol. 36, pp. 9-28

Phillips, J. J. (1996), Accountability in Human Resource Management, Gulf Publishing Company, Houston

Pološki Vokić, N. (2004), "Human resource management in big Croatian companies", Ekonomski Pregled, 55(5-6), pp. 455-478

Pološki Vokić, N., Frajlić, D. (2004), “Croatian labour force competitiveness indicators: Results of empirical research", in P. Bejaković, J. Lowether: Croatian human resource competitiveness study, Zagreb, Institut za javne financije

Pološki Vokić, N., Vidović, M. (2008), “HRM as a Significant Factor for Achieving Competitiveness through People: The Croatian Case”, International Advanced Economic Research, Vol. 14, pp. 303-315

Samuelson,P.A., Nordhaus,W.D. (1993), Ekonomija, Mate, Zagreb

Schuler, R.S., Jackson, S.E. (1987), “Linking competitive advantage with human resource management practices", Academy of Management Executive, Vol. 1, pp. 207-219

Shultz,T.W. (1985), Ulaganje u ljude, CEKADE, Zagreb
Šošić, I. (2006), Primijenjena statistika, Školska knjiga, Zagreb

Tichy, N. M., Fombrun, C. J., Devanna, M. A. (1982), "Strategic Human Resource Management", Sloan Management Review, Vol. 23 Issue 2, pp. 47-61

Terpstra, D.E., Rozell, E.J. (1993), “The relationship of staffing practices to organizational level measures of performance", Personnel Psychology, Vol. 46 , pp. $27-48$

Ulrich, D. (1997), Human Resource Champions - The Next Agenda for Adding Value and Delivering Results, Harvard Business School Press, Boston, MA

Ulrich, D., Geller, A., DeSouza, G. (1984), "A strategy, structure, human resource data base: OASIS", Human Resource Management, Vol. 23, pp. 77-90

www.dzs.hr

www.oecd.org

http://www.conference-board.org/data/ bcicountry.cfm? cid $=1$

http://www.hnb.hr/tecajn/htecajn.htm, 8.1.2013.

www.hgk.hr

www.efzg.hr/ Mali leksikon odgoja, obrazovanja i školstva, prof.dr.sc. Vinko Barić

www.poslovna.hr 